\title{
Serum levels of the soluble hemoglobin-scavenger receptor CD163 in MPO-ANCA-associated renal vasculitis
}

Supplementary Table 1. Serum soluble CD163 levels correlation among 11 groups

\begin{tabular}{|c|c|c|c|c|c|c|c|c|c|c|c|c|}
\hline & & \multicolumn{3}{|c|}{ Active vasculitis } & \multicolumn{3}{|c|}{ Inactive vasculitis } & \multicolumn{3}{|c|}{$\begin{array}{l}\text { Inactive vasculitis } \\
\text { with infection }\end{array}$} & \multirow{2}{*}{$\begin{array}{l}\text { Infectious } \\
\text { controls }\end{array}$} & \multirow{2}{*}{$\begin{array}{l}\text { Normal } \\
\text { controls }\end{array}$} \\
\hline & & $\mathrm{AH}$ & ILD & none & $\mathrm{AH}$ & ILD & none & $\mathrm{AH}$ & ILD & none & & \\
\hline \multirow{2}{*}{$\begin{array}{l}\text { Active } \\
\text { vasculitis }\end{array}$} & ILD & $<0.0001$ & - & 0.0361 & 0.3679 & 0.0147 & 0.0059 & $<0.0001$ & 0.0001 & $<0.0001$ & 0.0034 & 0.0015 \\
\hline & none & $<0.0001$ & 0.0361 & - & 0.0152 & $<0.0001$ & $<0.0001$ & 0.0008 & 0.0855 & 0.0152 & 0.5480 & $<0.0001$ \\
\hline \multirow{2}{*}{$\begin{array}{l}\text { Inactive } \\
\text { vasculitis }\end{array}$} & $\mathrm{AH}$ & 0.0001 & 0.3679 & 0.0152 & - & 0.3675 & 0.2352 & $<0.0001$ & 0.0002 & $<0.0001$ & 0.0005 & 0.2161 \\
\hline & none & 0.0007 & 0.0059 & $<0.0001$ & 0.2352 & 0.6845 & - & $<0.0001$ & $<0.0001$ & $<0.0001$ & $<0.0001$ & 0.9362 \\
\hline \multirow{3}{*}{$\begin{array}{l}\text { With } \\
\text { infection }\end{array}$} & $\mathrm{AH}$ & $<0.0001$ & $<0.0001$ & 0.0008 & $<0.0001$ & $<0.0001$ & $<0.0001$ & - & 0.0273 & 0.4054 & 0.0021 & $<0.0001$ \\
\hline & ILD & $<0.0001$ & 0.0001 & 0.0855 & 0.0002 & $<0.0001$ & $<0.0001$ & 0.0273 & - & 0.0908 & 0.2068 & $<0.0001$ \\
\hline & none & $<0.0001$ & $<0.0001$ & 0.0152 & $<0.0001$ & $<0.0001$ & $<0.0001$ & 0.4054 & 0.0908 & - & 0.0045 & $<0.0001$ \\
\hline \multicolumn{2}{|c|}{ Infectious controls } & $<0.0001$ & 0.0034 & 0.5480 & 0.0005 & $<0.0001$ & $<0.0001$ & 0.0021 & 0.2068 & 0.0045 & - & $<0.0001$ \\
\hline
\end{tabular}

AH, patients with alveolar hemorrhage; ILD, patients with interstitial lung disease; none, patients without pulmonary involvement.

P-values $<0.0009$ were accepted as significant in the multiple comparisons. 